\title{
Dualism of Regulation of Criminal Law in Aceh:Criticizing the Neglected Legal Certainty
}

\author{
Liza Agnesta Krisna ${ }^{1}$, and Kuat Puji Prayitno ${ }^{1}$ \\ \{agnes_krisna@ymail.com, kuatunsoed@yahoo.com\} \\ ${ }^{1}$ Departemen of Law, Samudra University, HR.Boenyt, Aceh, Indonesia \\ ${ }^{2}$ Departmen of Criminal Law, Jenderal Soedirman, HR.Boenyamin Street, Semarang, Indonesia
}

\begin{abstract}
The purpose of this study is to analyze the dualism of the regulation of criminal law in Aceh after the enactment of Qanun No. 6 year 2014 regarding Jinayat Law which resulted in the uncertainty of the implementing of criminal law. The research approach is statute approach using secondary data that deeply discussed the contents of a written document. But in this research also use empirical method by conducting interview to one of the District Court judge. In reality there is a dualism of regulation of criminal law in Aceh. The data shows that the act of sexual abuse and rape of children there are 2 (two) First, Law No. 35 Year 2014 on Amendment to Law No. 23 Year 2002 regarding Child Protection, the trial was carried out by District Court and second, Qanun No. 6 Year 2014 regarding Jinayat Law which is trial was carried out by the Syar'iyah Court. The background of this dualism is the disagreement between law enforcer in Aceh and the consideration of sanctions contained in the qanun is lower than the law. This dualism resulted in legal certainty for the defendants, victims and the public.
\end{abstract}

Keywords: Aceh, Criminal, Dualism, Regulation

\section{INTRODUCTION}

Since the founding of the Unitary State of the Republic of Indonesia, the founders of the State are aware that the existence of a plural society is the wealth of the Indonesian nation that must be recognized, accepted and respected, and then manifested by the motto of Bhineka Tunggal Ika. Indonesia consists of 17,504 islands (16,056 islands have been verified) [1]. With a population of over $263,846,946$ million in 2016, it consists of 714 tribes and 35 provinces. For the State of Indonesia which has such complex heterogeneity with high disintegration potential requires every step and its policy directed to strengthen national unity and unity.

One such policy is the handover of special autonomy to the province of Aceh through Law No. 44 Year 1999 regarding the Implementation of Special Feature of Aceh Province and Law No. 18 Year 2001 regarding Special Autonomy for the Special Province of Aceh. Aceh is one of the provinces in Indonesia which has a long history of armed conflict between the Free Aceh Movement (GAM) led by Tengku Muhammad Hasan Tiro and the government of Republic Indonesia since 1976. The handover of special autonomy through Law No. 18 Year 
2001 has not been able to reconcile the conflict in Aceh. Peace is achieved through a peace agreement between the government of Republic Indonesia and Aceh called Memorandum of Understanding (MoU) Helsinki. The Helsinki MoU was signed in Helsinki, Finland on 15 August 2005.

The Government of the Republic Indonesia and the Free Aceh Movement (GAM) affirmed their commitment to resolution of the Aceh conflict on peaceful, comprehensive, sustainable and dignified for all. The parties are determined to create conditions so that the Aceh government can be realized through a democratic and fair process within the unitary state and the Republic of Indonesia constitution. The parties absolutely believe that only by peaceful resolution of the conflict which will enable the reconstruction of Aceh post-Tsunami on 26 December 2004 can achieve progress and success. The parties involved in the conflict are determined to build mutual trust [2]

One of the points in the Helsinki MoU is the birth of Law No. 11 Year 2006 regarding the Government of Aceh as well as replacing Law No. 18 Year 2001. This Law was born on the consideration that the system of government of the Unitary State of the Republic of Indonesia according to the Constitution of the Unitary State of the Republic of Indonesia Year 1945 recognizes and respects the units of special local government or special nature which is governed by this Act [3]

Compulsory matters which are the authority of the Aceh government in the implementation of Aceh's privileges include the implementation of religious life in the form of implementation of Islamic Shari'ah for adherents in Aceh while maintaining the harmony of interfaith life (Article 16 (2) point a, [3]. The provisions of the implementation of the law relating to the authority of the Aceh government are established by qanun.

On October 22, 2014, the Aceh government ratified Qanun No. 6 year 2014 regarding Jinayat Law which became effective 1 (one) year after it was enacted. In principle this qanun is the implementation of Islamic Shari'ah in Aceh, so the government of Aceh deem it necessary to regulate a legal provisions on criminal acts in accordance with Islamic Shari'ah is against criminal acts that have a different understanding with the provisions of criminal law applicable in Indonesia. As for criminal acts that are not regulated in qanun, still follow the Criminal Code (Criminal Code) and the Special Criminal Law outside the Criminal Code. The judicial process for Qanun No.6 year 2014 regarding Jinayat Law is implemented in the Syar'iyah Court. Qanun No. 10 Year 2002 regarding Islamic Shari'ah Courts regulates the authority of the Mahkamah Syar'iyah that examines, decides and resolves the case on the first level in the field of al-ahwal al-shakhsyiah, muamalah, and jinayah [4]

Based on the above description, there are 2 (two) criminal law in Aceh: (a) Qanun No. 6 year 2014 regarding Jinayat Law and the Law (KUHP) and Special Criminal Law outside the Criminal Code. It is interesting to analyze whether there is a dualism of the criminal law arrangement in Aceh that leads to the uncertainty of the application of criminal law.

\section{LITERATURE REVIEW}

Qanun is a legislative regulation similar to a provincial regulation governing the governance of the Acehnese community life. In fact the qanun is not exactly in line with the local regulations, although in terms of qanun mentioned as a local regulation, but he is given special powers that is the rule of direct implementation for the law in special autonomy affairs. In other words, qanun is a hierarchical exercise directly under Law No. 11 Year 2006 
regarding the Government of Aceh, so that Law No. 11 Year 2006 may override other laws and regulations by following the lex principle of specialist derogate lex generalist. There are several principles to be considered in the lex specialist generalist derogate lex generalist:

a. The provisions found in general rules of law remain in force unless they are specifically regulated in these particular legal rules.

In relation to the regulation of criminal law in Aceh, general criminal law arrangements may be disregarded if they have been specifically regulated in qanunHukumJinayat.

b. The lex specialist provisions shall be equal to the terms of lex generalist (statute by law).

In relation to the regulation of criminal law in Aceh, qanun is a direct implementation regulation of Law No 11 Year 2006 regarding the Government of Aceh, so that Law No 11 Year 2006 becomes equivalent to the Criminal Code and Special Criminal Law outside the Criminal Code

c. Thelex specialist provisions are in the same legal environment as the lex generalist.

In relation to the regulation of criminal law in Aceh, qanun of Jinayat Law has the same legal environment as the Criminal Code and the Special Criminal Law outside the Criminal Code, which equally stipulates the criminal act.

The word Jinayah is a verbal noun (masdar) form of the word jana. Etymologically the word jana means to sin or wrong, while jinayah is defined as a sin or wrongdoing. The word Jinayah in legal terms is often referred to as a criminal act or delict. The word Jinayah has an understanding as expressed by Imam al-Mawardi namely: jarimah are acts prohibited by syara 'which is threatened by Allah with hadd or ta'zir law. [4]

According to Achmad Ali there are 3 conventional streams about the purpose of law, namely:[5]

a. Ethical flow, namely to assume that basically the purpose of law is solely to achieve justice;

b. The flow of utilities, namely assuming that basically the purpose of law is solely to create the benefit or happiness of the citizens;

c. The dogmatic juridical flow is to assume that basically the purpose of law is solely to create legal certainty.

\section{METHODS}

This research used is normative juridical. The main characteristic of this is to use the main source of library materials or secondary data. Approach method used in this research is statute approach (statute approach). But in this study also uses sociological / empirical method by conducting interviews to one of the District Court judges.

\section{RESULT AND DISCUSSION}

\subsection{Dualism of Regulation of Criminal Law in Aceh}

Qanun No. 6 year 2014 regarding Jinayat Law (hereinafter referred to QanunHukumJinayat) consists of 10 (ten) Chapters and 75 (seventy five) Articles. There are 10 (ten) criminal acts regulated in qanun, that is:

a. Khamar; 

b. Maisir;
c. Khalwat;
d. Ikhtilat;
e. Zina;
f. Sexual Abuse;
g. Rape;
h. Qadzaf;
i. Liwath, and;
j. Musahaqah

Table 1. The explanation of the criminal act

\begin{tabular}{|c|c|c|c|}
\hline $\begin{array}{l}\text { Criminal } \\
\text { Acts }\end{array}$ & Details of Actions & The Criminal Code & $\begin{array}{lr}\text { The } & \text { Special } \\
\text { Criminal Law } \\
\text { outside re } \\
\text { Criminal Code }\end{array}$ \\
\hline Khamar & $\begin{array}{l}\text { Intoxicant and/or alcoholic } \\
\text { beverages of } 2 \% \text { (two } \\
\text { percent) or more }\end{array}$ & $\begin{array}{l}\text { Article } 492 \text { and Article } \\
\text { 536(having an element of } \\
\text { criminal act different from } \\
\text { qanun) }\end{array}$ & - \\
\hline Maisir & $\begin{array}{l}\text { an act containing the } \\
\text { element of betting and / or } \\
\text { an element of chance made } \\
\text { between } 2 \text { (two) or more } \\
\text { parties, accompanied by an } \\
\text { agreement that the winning } \\
\text { party will be paid a certain } \\
\text { benefit from the losers } \\
\text { either directly or indirectly. }\end{array}$ & $\begin{array}{l}\text { Article } 303 \\
\text { (having an element of } \\
\text { criminal act different from } \\
\text { qanun) }\end{array}$ & - \\
\hline Khalwat & $\begin{array}{l}\text { The act of being in a closed } \\
\text { or hidden place between } 2 \\
\text { (two) people of different } \\
\text { sex not mahram and } \\
\text { without marital bond with } \\
\text { the willingness of both } \\
\text { parties that lead to the act } \\
\text { of adultery }\end{array}$ & - & - \\
\hline Ikhtilat & $\begin{array}{l}\text { The act of making out like } \\
\text { making out, touching, } \\
\text { hugging and kissing } \\
\text { between men and women } \\
\text { who are not husband and } \\
\text { wife with the willingness of } \\
\text { both parties that lead to the } \\
\text { act of adultery }\end{array}$ & - & - \\
\hline Zina & Intercourse between a man & Article 284 & - \\
\hline
\end{tabular}




\begin{tabular}{|c|c|c|c|}
\hline & $\begin{array}{l}\text { or more with a woman or } \\
\text { more without marital ties } \\
\text { with the willingness of both } \\
\text { parties }\end{array}$ & $\begin{array}{l}\text { (having an element of } \\
\text { criminal act different from } \\
\text { qanun) }\end{array}$ & \\
\hline $\begin{array}{l}\text { Sexual } \\
\text { Abuse }\end{array}$ & $\begin{array}{l}\text { By deliberately sexually } \\
\text { abusing children }\end{array}$ & $\begin{array}{l}\text { Article } 287 \\
\text { (has been ruled out by the } \\
\text { Special Law outside the } \\
\text { Criminal Code) }\end{array}$ & $\begin{array}{lr}\text { Law Number } & 35 \\
\text { Year 2014 } & \text { on } \\
\text { Amendment } & \text { to } \\
\text { Law Number } & 23 \\
\text { Year } & 2002 \\
\text { regarding } & \text { Child } \\
\text { Protection }\end{array}$ \\
\hline Rape & $\begin{array}{l}\text { Deliberate rape of both } \\
\text { male and female children }\end{array}$ & $\begin{array}{l}\text { Article } 285 \\
\text { (has been ruled out by the } \\
\text { Special Law outside the } \\
\text { Criminal Code) }\end{array}$ & $\begin{array}{lrr}\text { Law Number } & 35 \\
\text { Year 2014 } & \text { on } \\
\text { Amendment } & \text { to } \\
\text { Law Number } & 23 \\
\text { Year } & 2002 \\
\text { regarding } & \text { Child } \\
\text { Protection } & \\
\end{array}$ \\
\hline Qadzaf & $\begin{array}{l}\text { Accuses a person } \\
\text { committing adultery } \\
\text { without being able to file at } \\
\text { least } 4 \text { (four) witnesses }\end{array}$ & - & - \\
\hline Liwath & $\begin{array}{l}\text { The act of a man by placing } \\
\text { his penis into the other male } \\
\text { anus with the willingness of } \\
\text { both parties }\end{array}$ & $\begin{array}{l}\text { Article } 292 \\
\text { Has an element of the } \\
\text { same act }\end{array}$ & - \\
\hline Musahaqah & $\begin{array}{l}\text { The act of two or more } \\
\text { women by mutually } \\
\text { rubbing limbs or faraj to } \\
\text { obtain sexual stimulation } \\
\text { (pleasure) with the } \\
\text { willingness of both parties }\end{array}$ & $\begin{array}{l}\text { Article } 292 \\
\text { Has an element of the } \\
\text { same act }\end{array}$ & - \\
\hline
\end{tabular}

Based on the above table there are some criminal acts regulated in qanun which actually has been alluded to in the Criminal Code, but has a different element of action. For example the act of khamar that is prohibition of liquor, in the Criminal Code Prohibition of liquors emphasized must fulfill the element disturb public order while in qanun there is no.

Problems arise in the regulation of criminal law for sexual abuse and rape of children. There is a dualism regulation of criminal law for the same act. Both actions are regulated in the first, Law No. 35 of 2014 on Amendment to Law No. 23 Year 2002 regarding Child Protection, and second, Qanun No. 6 Year 2014 regarding Jinayat Law.

In fact in Aceh for sexual harassment and rape of children, law enforcement is still confused to determine its criminal law arrangements, whether to use Law No. 35 Year 2014 or Qanun No. 6 years 2014. Furthermore, the use of criminal law arrangements on these two acts affects the jurisdiction of the judiciary who will examine, hear and decide the sentence for the defendant. If law enforcers use Law No. 35 Year 2014 then the judicial institution authorized 
to adjudicate is The District Court whereas if law enforcement uses Qanun No. 6 year 2014 then the judicial institution authorized to adjudicate is the TheSyar'iyah Court.

HeriKurniawan said there is still debate and dissent among law enforcers in Aceh about the use of material criminal law against both actions. Prosecutors argue that qanun is only a regional regulation so that it is not equal to Law No. 35 Year 2014 so that the prosecutor's office will file a case to the District Court while in our opinion that after the enactment of qanun, criminal acts regulated in the qanun must be submitted to the Court syar'iyah as a judiciary that hasabsolute authority for the enforcement of qanun. Furthermore, if viewed from the aspect of the duration of criminal sanctions in the form of prison in qanun is lower than the Law No. 35 year 2014. This is also a consideration in choosing the regulations used by law enforcer.

Table 2. Dualism of regulation of criminal law in Aceh can be seen from the table of judges verdict

\begin{tabular}{lll}
\hline Year & District Court & Court syar'iyah \\
\hline 2016 & Nomor & Nomor \\
& 268/Pid.Sus/2016/P & 06/JN/2016/MS.Lgs \\
& N.Idi & \\
2016 & Nomor & Nomor \\
& 294/Pid.Sus/2016/P & 014/JN/2016/MS.Lg \\
& N.Ksp & s \\
2017 & Nomor & Nomor \\
& 28/Pid.B/2017/PN.L & 02/JN/2017/MS.Lgs \\
& gs & \\
\hline
\end{tabular}

Based on the above table shows that there are still discrepancies and differences of opinion between law enforcers regarding which criminal law arrangements are used against sexual abuse and rape of children. For both acts law enforcers have no certainty of the enforcement of the criminal law that is held, so even though the legal qanunofJinayat Law has been applied, there are still sexual abuse and rape cases prosecuted by the District Court.

Table 3. Terms of the sanctions difference between the two criminal regulations

\begin{tabular}{|c|c|c|}
\hline Criminal Acts & $\begin{array}{l}\text { Law No } 35 \text { Year } 2014 \text { on } \\
\text { Amendment to Law No } 23 \text { Year } 2002 \\
\text { regarding Child Protection }\end{array}$ & $\begin{array}{l}\text { Qanun No. } 6 \text { Year } 2014 \\
\text { regardingJinayat Law }\end{array}$ \\
\hline $\begin{array}{l}\text { Sexual Abuse } \\
\text { Against Children }\end{array}$ & $\begin{array}{l}\text { Penal sanctions are a minimum of } 5 \\
\text { (five) years and a maximum of } 15 \\
\text { (fifteen) years and a maximum fine } \\
\text { of Rp 5,000,000,000.00 (five billion } \\
\text { rupiahs). } \\
\text { In the case of sexual abuse done by } \\
\text { Parents, Guardians, Nannies, } \\
\text { educators, or educational personnel, } \\
\text { the penalty added } 1 / 3 \text { (one third) of } \\
\text { the above criminal penalty = } \\
\text { maximum } 20 \text { years imprisonment }\end{array}$ & $\begin{array}{l}\text { Criminal sanctions: } \\
\text { at most } 90 \text { (ninety) times whips, } \\
\text { or; } \\
\text { a fine of at most } 900 \text { (nine } \\
\text { hundred) grams of pure gold, or; } \\
\text { prison at the latest } 90 \text { (Ninety } \\
\text { months) }=7.5 \text { years }\end{array}$ \\
\hline $\begin{array}{l}\text { Rape Against } \\
\text { Children }\end{array}$ & $\begin{array}{l}\text { Penal sanctions are a minimum of } 5 \\
\text { (five) years and a maximum of } 15\end{array}$ & $\begin{array}{l}\text { Criminal sanctions of at least } \\
150 \text { (one hundred and fifty) at }\end{array}$ \\
\hline
\end{tabular}



(fifteen) years and a maximum fine
of Rp 5,000,000,000.00 (five billion
rupiahs)
In the case of rape committed by the
Parent, Guardian, Child Caregiver,
educator, or educational staff, the
penalty added $1 / 3$ (one third) of the
above criminal penalty = maximum
20 years imprisonment most 200 (two hundred) times of whips, or;

a fine of at least 1,500 (one thousand five hundred) grams of pure gold or at most 2,000 (two thousand) grams of pure gold, or; prison at least 150 (one hundred and fifty) months at most 200 (two hundred) months = at least 12.5 years at most 16.7 years

Based on the above table shows that correct in terms of criminal punishment in the form of prison, the prison sentence in Qanun No. 6 year 2014 is lower than the imprisonment in Law No. 35 year 2014. The question arises further whether the size of the duration of imprisonment can bring justice for victims and the community? In the opinion of the author as a researcher in the field of protection of children. Up to now law enforcement on the protection of children as victims is only through the conviction of the perpetrators. There has been no implementation of compensation or the fulfillment of the right of restitution from the perpetrator against the victim. While the impacts of child victims of sexual violence is very complex. because not only the material losses suffered by victims but the loss of inmaterialil that impact long and damage the future of the child. Therefore, the hope of the victim and the community must be to the fullest possible penalty and worth the loss of the natural victim.

While to assess the deterrent effect caused to the perpetrator between whip and prison imprisonment is still difficult to conclude there must be a separate research. Until now there is no agreement between law enforcers and the policies issued by the Supreme Court in resolving the dualism of the criminal law in Aceh. The current situation is a waiver of legal certainty for both the perpetrator, the victim and the public. The neglected legal certainty results in no clarity for the direction of future law enforcement and any possible "judicialdecision" possibility to be given to a similar case in the future.

Basically if the regulation of criminal law in Aceh is qanunjinayat law is returned to the principle of the principle of Islamic personality and territorial principle then there are 4 (four) kinds of guidelines are:

a) For the Muslim community in Aceh who committed criminal acts in Aceh automatically qanunjinayat law applied to them

b) For other Muslim communities (Muslim communities in Aceh) who commit criminal acts in Aceh automatically qanunjinayat laws apply to them

c) For non-Muslim communities in Aceh who commit criminal acts in Aceh or outside Aceh does not apply qanunjinayat law so that the applicable Criminal Code or Special Act outside the Criminal Code

d) For the Muslim community in Aceh who committed criminal acts outside Aceh is not enacted qanunjinayat law so that the applicable Criminal Code or Special Act outside the Criminal Code

e) Looking at the concept of justice and legality according to Hans Kelsen it is said that to uphold on the basis of a solid of a certain social order, according to Hans the notion of "justice" means legality. A general rule is "fair" if it is actually applied, while a general rule is "unfair" if applied to a case and not applied to other similar cases. The concept of justice and legality is applied in the national law of the Indonesian nation, which means that the rule of national law can be used as an 
umbrella law for other regulations of national law in accordance with the level and degree of the rule of law that has the power to bind to the material that is loaded (content material) in the rule of law. [6]

\section{CONCLUSION}

Dualism of regulation of criminal law takes place in Aceh. This is evidenced by the data table showing the act of sexual abuse and rape of children there are 2 (two) legal regulations: first, Law No. 35 year 2014 on Amendment to Law No. 23 year 2002 regarding Child Protection, and second, Qanun No. 6 year 2014 regardingJinayat Law. The background of this dualism is the disagreement between law enforcement in Aceh and the sanctions contained in the qanun are more rendering than the law. The dualism of this regulations impacts on the different judicial institutions that judge. This has been happening for the last 3 years since the enactment of qanun No. 6 year 2014 so far it has resulted in legal certainty for the perpetrators, victims and the neglected community.

\section{REFERENCES}

[1] http://news.kkp.go.id, “Indonesia Laporkan 16.056 Pulau Bernama ke PBB," http://news.kkp.go.id, 2017.

[2] T. Government, F. A. Movement, and T. Memorandum, "MoU Helsinki," 2004.

[3] K. L. N. Indonesia, Law No. 11 Year 2006 regarding the Government of Aceh. 2006.

[4] Zulkarnain Lubis dan Bakti Ritonga, Dasar-Dasar Hukum Acara Jinayah, 1 April 20. Jakarta: Prenadamedia Group, 2016.

[5] A. Ali, Menguak Teori Hukum (Legal Theory) dan Teori Peradilan (Judicial Prudence), Cetakan ke. Jakarta: Prenadamedia Group, 2012.

[6] M. Effendy, Teori Hukum dari perspektif kebijakan, perbandingan dan harmonisasi hukum pidana, 1st ed. Ciputat jakarta: Gaung Persada Press Group, 2014. 